\title{
Bison Weights From National Parks in the Northern Great Plains
}

\author{
By Daniel S. Licht
}

\section{On the Ground}

- Female bison at three Northern Great Plains parks reached maximum size at 5.5 years of age. Male bison reached maximum size around 10.5 years of age.

- The mean weight for females 5.5 years old and older was $473 \mathrm{~kg}$, and for males 10.5 years old and older was $816 \mathrm{~kg}$. The mean weight for yearling females was $307 \mathrm{~kg}$, and for yearling males was $325 \mathrm{~kg}$.

- There were significant differences in bison weights between the three parks even though the herds were all stocked well below the forage-based carrying capacity.

- Heavier calves and yearlings tended to be heavier adults; however, there was much variability among individuals.

- Accurate and unambiguous data on bison weights can be used to set stocking rates and make other management decisions and therefore should be collected whenever possible.

Keywords: age, bison, great plains, national parks, sex, weight.

Rangelands 38(3):138-144

doi 10.1016/j.rala.2016.02.003

(c) 2016 The Society for Range Management

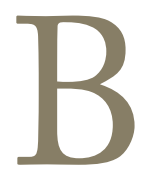

ison (Bison bison), also known as buffalo, are the largest native grazer in the North American Great Plains, and when present can comprise more biomass per area than any other native fauna. Bison carrying capacity and stocking rates are often determined in part on known or assumed bison weights, ${ }^{1}$ therefore, accurate and detailed information on weights is needed. However, unambiguous age, sex, and regional-specific information on bison weights are surprisingly sparse in the scientific literature (for a summary see Reynolds et al. ${ }^{2}$ ).
Badlands, Theodore Roosevelt, and Wind Cave National Parks (NP), located in the Northern Great Plains of North America, have a long history of bison management. The parks routinely round up bison for the primary purpose of culling surplus animals. As part of that effort animals are given unique lifetime marks that facilitate accurate aging. A suite of biological data is also collected, including weight information. I present and analyze bison weight data from the three parks from 1983-2014.

\section{Background on the Three Herds}

Badlands, Theodore Roosevelt, and Wind Cave NPs manage their bison herds per National Park Service policies. ${ }^{3}$ The policies call for the conservation of natural processes and conditions to the extent possible, with minimal anthropogenic intervention. The herds are confined to the parks year-round by a 2.1-2.4 $\mathrm{m}$ high woven-wire fence and natural barriers. There is no cross-fencing or pasture rotation. The parks do not provide supplemental feed or minerals for the bison. There is no forced weaning. The animals are not provided growth hormones, antibiotics, or other treatments sometimes given to cattle or privately-owned bison herds. Culled animals are selected randomly within a cohort, i.e., selection is not based on morphological characteristics; however, selective culling apparently occurred to an unknown extent in the early years of bison management at the parks. As a result of these policies and practices the herds are classified by some as "conservation herds". 4

\section{Badlands National Park}

Badlands NP lies in southwestern South Dakota (lat $43^{\circ} 51^{\prime} 00$ ”'N, long $102^{\circ} 20^{\prime} 00^{\prime \prime} \mathrm{W}$ ) about $11 \mathrm{~km}$ south of Wall, South Dakota. Habitat within the park consists of a mosaic of rugged and barren badlands topography intermixed with flatter areas of mixed-grass prairie. Dominant vegetation in the prairie includes western wheatgrass (Pascopyrum smithii), green needlegrass (Nassella viridula), and little bluestem (Schizachyrium scoparium). Average rainfall is about $41 \mathrm{~cm}$. Natural Resources Conservation Service (NRCS) plant productivity data ${ }^{5}$ indicates that the 19,500 ha available to bison produce about 26.2 million $\mathrm{kg}$ of forage in a 
Table 1. Modeled composition of the herds when subjected to an annual $16 \%$ cull of all cohorts

\begin{tabular}{|l|c|c|}
\hline Age & \% Female & \% Male \\
\hline 0.5 & 10.2 & 10.2 \\
\hline 1.5 & 8.4 & 8.2 \\
\hline 2.5 & 6.9 & 6.7 \\
\hline 3.5 & 5.5 & 4.9 \\
\hline 4.5 & 4.4 & 3.5 \\
\hline 5.5 & 3.5 & 2.7 \\
\hline 6.5 & 2.9 & 2.0 \\
\hline 7.5 & 2.4 & 1.6 \\
\hline 8.5 & 2.0 & 1.1 \\
\hline 9.5 & 1.8 & 0.9 \\
\hline $10.5+$ & 6.9 & 3.3 \\
\hline Total & 55.0 & 45.0 \\
\hline
\end{tabular}

normal-precipitation year. Bison were reintroduced to the park in 1963. Fifty of the founder animals came from Theodore Roosevelt NP and three from Fort Niobrara National Wildlife Refuge. Another 20 bison were supplemented in 1984 from Colorado National Monument. The park manages for a population of 700 bison, a level based on drought conditions. ${ }^{6}$ The bison probably consume about $12 \%$ of plant productivity in a normal-precipitation year.

\section{Theodore Roosevelt National Park}

Theodore Roosevelt NP is located in western North Dakota. The park consists of a South Unit (lat 46 $58^{\prime} 00^{\prime \prime} \mathrm{N}$, long $103^{\circ} 30^{\prime} 00^{\prime} \mathrm{W}$ ) immediately north of Medora, North Dakota, and a North Unit (lat $47^{\circ} 36^{\prime} 00^{\prime \prime} \mathrm{N}$, long $\left.103^{\circ} 23^{\prime} 00^{\prime \prime} \mathrm{W}\right) 21 \mathrm{~km}$ south of Watford City, North Dakota. The South Unit has about 18,400 ha available to bison and the North Unit has about 9,600 ha. Habitat within the two units consists of a mosaic of rugged and barren badlands topography intermixed with flatter areas of mixed-grass prairie. Dominant vegetation in the prairie includes needle-and-thread (Hesperostipa comate), green needlegrass, and western wheatgrass. Average rainfall is about $38 \mathrm{~cm}$. Based on NRCS data ${ }^{5}$ the South Unit produces about 23.6 million $\mathrm{kg}$ of forage and the North Unit about 12.7 million $\mathrm{kg}$ in a normal-precipitation year. Twenty-nine bison were reintroduced to the park in 1956 from Fort Niobrara National Wildlife Refuge in Nebraska. The park manages for a population of 200-500 bison in the South Unit and 100-300 in the North Unit, which equate to forage allocations of about $7 \%$ for each herd. Other notable grazing ungulates include about 360 elk (Cervus canadensis) and 100 feral horses (Equus caballus) in the South Unit.

\section{Wind Cave National Park}

Wind Cave NP (lat $43^{\circ} 36^{\prime} 00^{\prime \prime} \mathrm{N}$, long $103^{\circ} 27^{\prime} 00^{\prime \prime} \mathrm{W}$ ) lies on the southern edge of the Black Hills $10 \mathrm{~km}$ north of Hot Springs, South Dakota. Habitat within the park consists of a mosaic of mixed-grass prairie and ponderosa pine (Pinus ponderosa) forests. Dominant vegetation in the prairie includes blue grama (Bouteloua gracilis), western wheatgrass, and little bluestem. Average rainfall is about $46 \mathrm{~cm}$. Based on NRCS plant productivity data ${ }^{5}$ the 11,500 -ha park produces about 18.7 million $\mathrm{kg}$ of forage in normal-precipitation years. Bison were reintroduced to the park in 1913 and 1916. Founder animals came from the New York Zoological Park and Yellowstone NP. The park manages for a winter population of 350-500 animals, which equates to a forage allocation of about $10 \%$ based on NRCS normal-year plant productivity data. Elk are the other noteworthy grazing ungulate; the park manages for a population of about 300 .

\section{Table 2. Fall weights of female bison}

\begin{tabular}{|c|c|c|c|c|c|c|}
\hline Location & Calves & Yearlings & 2.5 & 3.5 & 4.5 & $5.5+$ \\
\hline Badlands NP & $\begin{array}{l}163 \pm 33 \\
52-270 \\
n=735\end{array}$ & $\begin{array}{l}329 \pm 47 \\
195-503 \\
n=705\end{array}$ & $\begin{array}{l}431 \pm 41 \\
257-580 \\
n=412\end{array}$ & $\begin{array}{l}457 \pm 42 \\
293-573 \\
n=236\end{array}$ & $\begin{array}{l}483 \pm 38 \\
373-563 \\
n=198\end{array}$ & $\begin{array}{l}505 \pm 46 \\
318-718 \\
n=1256\end{array}$ \\
\hline Theodore Roosevelt NP & $\begin{array}{l}147 \pm 30 \\
50-212 \\
n=131\end{array}$ & $\begin{array}{l}320 \pm 49 \\
181-440 \\
n=212\end{array}$ & $\begin{array}{l}413 \pm 32 \\
310-499 \\
n=107\end{array}$ & $\begin{array}{l}446 \pm 37 \\
363-553 \\
n=82\end{array}$ & $\begin{array}{l}463 \pm 49 \\
329-574 \\
n=75\end{array}$ & $\begin{array}{l}484 \pm 42 \\
337-590 \\
n=179\end{array}$ \\
\hline Wind Cave NP & $\begin{array}{l}132 \pm 30 \\
28-225 \\
n=276\end{array}$ & $\begin{array}{l}273 \pm 49 \\
156-435 \\
n=840\end{array}$ & $\begin{array}{l}362 \pm 40 \\
218-488 \\
n=341\end{array}$ & $\begin{array}{l}383 \pm 45 \\
259-517 \\
n=248\end{array}$ & $\begin{array}{l}402 \pm 35 \\
290-502 \\
n=187\end{array}$ & $\begin{array}{l}430 \pm 41 \\
302-603 \\
n=1294\end{array}$ \\
\hline $\begin{array}{l}\text { Mean among parks unadjusted } \\
\text { for sample size }\end{array}$ & 147 & 307 & 402 & 429 & 449 & 473 \\
\hline
\end{tabular}

First value is mean weight $(\mathrm{kg})$ followed by SD. Numbers in italics are minimum and maximum. $\mathrm{n}=$ sample size. 
Weights of Bison by Age at Badlands National Park

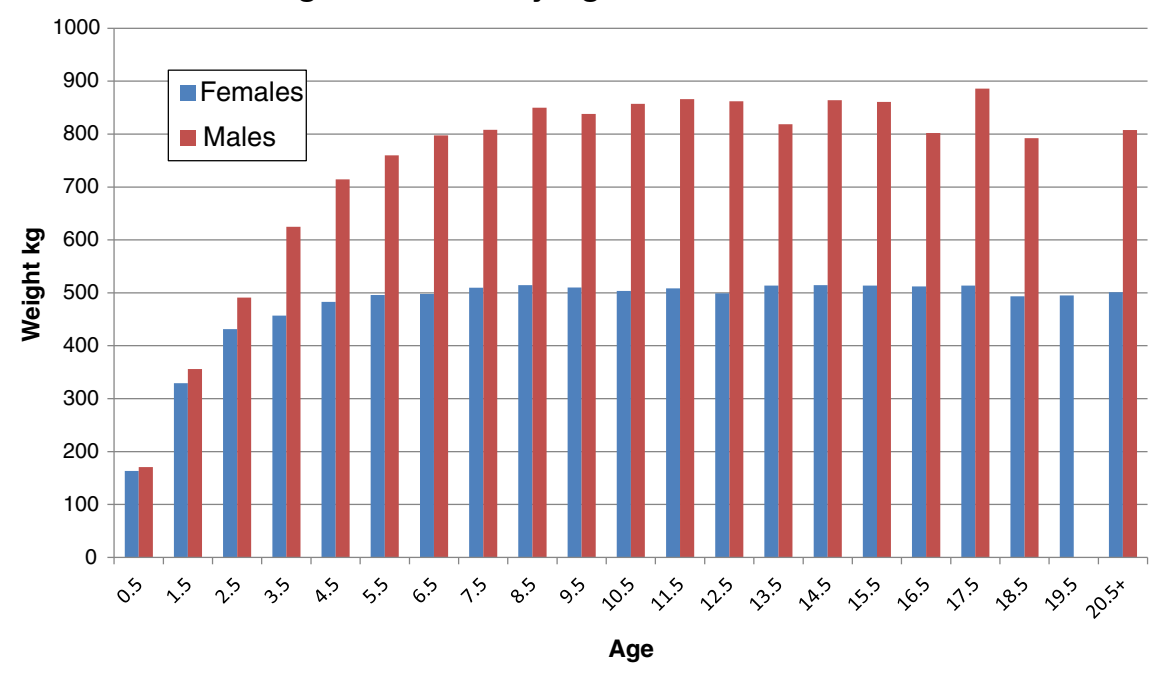

Figure 1. Mean bison weights (kg) for Badlands NP by sex and age.

How the Information Was Collected and Analyzed

The three parks rounded up bison in September-November of most years from 1983-2014 for the primary purpose of removing surplus animals. The roundups typically collected most, if not all, of the cow-calf herds; however, bachelor herds and single bulls were generally avoided, as they were difficult and dangerous to handle. Captured adult bulls were typically pushed into the corrals as part of a cow-calf herd. Captured animals were individually pushed into a restraining chute where they were processed. Calves and other un-marked animals were marked with a uniquely-numbered external ear tag and a uniquely-numbered passive microchip injected subcutaneously in the ear. Calves were identified by coloration, size, horn development, association with a cow, and if necessary, tooth eruption. ${ }^{7}$ The age of other un-marked animals was estimated based on tooth eruption and wear. Weights were recorded via a scale located in the restraining chute. Scales were typically calibrated by having multiple people of known weight stand on the scales before the roundups and periodically during the roundups. Weight and other information were logged in a park-specific bison database.

From each database I retrieved all records with complete sex, age, and weight data. Outliers were identified using nonlinear regression ${ }^{8}$ and box plots for each park/gender/age subset. Outliers were retained if they were deemed plausible, e.g., if injuries were reported for an exceptionally lightweight animal, or an extraordinarily heavy animal retained the heavy weight across the years. Non-sensible records were removed.

\section{Table 3. Fall weights of males}

\begin{tabular}{|c|c|c|c|c|c|}
\hline Location & Calves & Yearlings & 2.5 & 3.5 & 4.5 \\
\hline $\begin{array}{l}\text { Badlands } \\
\text { NP }\end{array}$ & $\begin{array}{l}171 \pm 37 \\
43-250 \\
n=734\end{array}$ & $\begin{array}{l}357 \pm 50 \\
191-548 \\
n=670\end{array}$ & $\begin{array}{l}492 \pm 54 \\
280-733 \\
n=385\end{array}$ & $\begin{array}{l}625 \pm 67 \\
476-813 \\
n=155\end{array}$ & $\begin{array}{l}714 \pm 78 \\
461-916 \\
n=113\end{array}$ \\
\hline $\begin{array}{l}\text { Theodore } \\
\text { Roosevelt } \\
\text { NP }\end{array}$ & $\begin{array}{l}153 \pm 32 \\
50-231 \\
n=134\end{array}$ & $\begin{array}{l}328 \pm 54 \\
156-488 \\
n=176\end{array}$ & $\begin{array}{l}453 \pm 54 \\
335-608 \\
n=88\end{array}$ & $\begin{array}{l}542 \pm 71 \\
420-744 \\
n=69\end{array}$ & $\begin{array}{l}597 \pm 70 \\
432-742 \\
n=50\end{array}$ \\
\hline $\begin{array}{l}\text { Wind Cave } \\
\text { NP }\end{array}$ & $\begin{array}{l}134 \pm 35 \\
22-210 \\
n=280\end{array}$ & $\begin{array}{l}289 \pm 52 \\
118-485 \\
n=883\end{array}$ & $\begin{array}{l}401 \pm 59 \\
245-544 \\
n=326\end{array}$ & $\begin{array}{l}521 \pm 64 \\
372-687 \\
n=138\end{array}$ & $\begin{array}{l}610 \pm 70 \\
456-737 \\
n=43\end{array}$ \\
\hline Mean among parks unadjusted for sample size & 153 & 325 & 449 & 563 & 641 \\
\hline
\end{tabular}

First value is mean weight $(\mathrm{kg})$ followed by SD. Numbers in italics are minimum and maximum. $\mathrm{n}=$ sample size. 
Wind Cave NP had the most frequent roundups and therefore a relatively large percentage of animals first marked as calves or yearlings. I used that park's database to look for bias in age estimation. I classified all records from animals first marked as calves or yearlings as records from known-age animals. Records from animals first marked at 2.5 years or older were classified as estimated-age records. Although bison in the 2-4-year-old range can be aged by tooth eruption and wear, ${ }^{7}$ the accuracy likely deteriorates in field conditions with wild un-sedated animals, hence, I assumed only calves and yearlings could be accurately aged. I conducted a 2-way analysis of variance (ANOVA) with classification type (i.e., known or estimated), and recorded age as factors to test for significant differences in weights between known-age and estimated-age records.

I tested for significant differences in weight among age and sex cohorts within the Badlands and Wind Cave NP herds using a two-way ANOVA. I did not run a similar test on the Theodore Roosevelt NP herd due to the small sample size. I subsequently pooled age classes that did not show a significant difference in weight. I then used a factorial ANOVA to test for differences in weights among the three parks. Results were considered significant if $P<0.05$.

For purposes of presenting the average weight of a bison within a herd I had to account for the sex and age composition of the herd. I used fecundity values from Millspaugh et al. ${ }^{9}$ and the mid-point of the survival rates from Millspaugh et al. ${ }^{9}$ and Pyne et al. ${ }^{6}$ to parameterize a demographic model; those studies used the Badlands and Wind Cave NP bison roundup databases. The modeled sex and age composition of a herd under an annual cull of $16 \%$ of each age and sex cohort is presented in Table 1. I also determined the average weight of a bison in a herd exposed to a yearling-only cull as that is what Wind Cave NP typically practices. ${ }^{9}$

I used linear regression to determine if calf and yearling weights were predictive of future weights for the same individual. To do this I retrieved subsets of bison from Badlands and Wind Cave NPs that were weighed as calves and again as yearlings, as calves and as fully-grown animals, and as yearlings and fully-grown animals.

\section{The Results}

The Badlands, Theodore Roosevelt, and Wind Cave NP bison roundup databases had 5,913, 4,915, and 9,118 records, respectively, from 1983-2014. I excluded all records with incomplete age, sex, and weight data and those with insensible outliers. The North Unit of Theodore Roosevelt NP accounted for only 156 usable records, all from 1985-1986, so I excluded that small dataset as well. The number of usable records from 1983-2014 was 5,886 for Badlands, 1,341 for Theodore Roosevelt (South Unit), and 4,927 for Wind Cave NP. Badlands NP had usable data from 9 years (2002-2014), Theodore Roosevelt NP (South Unit) had data from 6 years (1992-2014), and Wind Cave NP had data from 24 years (1983-2014).

Of the Wind Cave NP records with usable weight data, 73\% came from animals marked as calves or yearlings. When I compared weights of females from that subset to weights of females aged by tooth eruption and wear there were no significant pairwise differences. I subsequently used all records from all parks regardless of whether the animal was marked as a calf or yearling, or its age was estimated later in life by tooth eruption and wear.

There were significant pairwise differences in weight among female age classes 0.5 to 5.5 at both Badlands and Wind Cave NPs (Table 2). There were no significant pairwise differences between female age classes 5.5 years old or older, suggesting maximum weight for females was about 5.5 years of age. A graph of Badlands NP females corroborated that conclusion (Fig. 1). Therefore, for subsequent analyses I pooled all records from females 5.5 years old or older. Weights of male bison were significantly different among age classes 0.5 to 5.5 at Wind Cave NP and 0.5 to 6.5 at Badlands NP (Table 3), but not among older age classes. However, the lack of statistical significance between age classes 6.5 to 10.5 might have been due to sample size as a graph of weights by age suggests that age of maximum weight for males may occur around 10.5 years of age (Fig. 1). For subsequent analyses I assumed differences between all age classes up to 10.5 at which point I pooled all records (Table 3). The graph also suggests a slight decline in biomass in the older age classes for both males and females; however, sample sizes were insufficient

\begin{tabular}{|l|l|l|l|l|l|}
$\mathbf{5}$ & \multicolumn{5}{l|}{} \\
\hline $\mathbf{5 . 5}$ & $\mathbf{6 . 5}$ & $\mathbf{7 . 5}$ & $\mathbf{8 . 5}$ & $\mathbf{9 . 5}$ & $\mathbf{1 0 . 5 +}$ \\
\hline $760 \pm 86$ & $798 \pm 70$ & $819 \pm 78$ & $850 \pm 54$ & $838 \pm 89$ & $852 \pm 71$ \\
$575-953$ & $645-934$ & $709-1021$ & $778-1034$ & $512-930$ & $635-1025$ \\
$n=51$ & $n=46$ & $n=28$ & $n=34$ & $n=22$ & $n=106$ \\
\hline $676 \pm 68$ & $764 \pm 42$ & $731 \pm 119$ & $802 \pm 57$ & $n=0$ & $873 \pm 99$ \\
$583-771$ & $689-846$ & $635-903$ & $730-862$ & & $653-998$ \\
$n=10$ & $n=11$ & $n=5$ & $n=4$ & & $n=8$ \\
\hline $678 \pm 77$ & $674 \pm 93$ & $701 \pm 78$ & $764 \pm 68$ & $782 \pm 57$ & $723 \pm 54$ \\
$517-853$ & $560-839$ & $578-828$ & $676-857$ & $703-839$ & $635-794$ \\
$n=31$ & $n=10$ & $n=13$ & $n=7$ & $n=4$ & $n=6$ \\
\hline 704 & 746 & 750 & 805 & 810 & 816 \\
\hline
\end{tabular}


for statistical analysis. Male weights were significantly greater than female weights within a park for the same age cohort for all ages except for calves at Theodore Roosevelt and Wind Cave NPs. The lack of statistical significance between male and female calf weights at those two parks is likely due to small sample sizes and wide variability in calf weights due to the number of days between when a calf was born and when the roundup was conducted.

Badlands NP females were significantly larger than Theodore Roosevelt NP females, which were significantly larger than Wind Cave NP females after controlling for the effects of age. Badlands NP males were larger than Theodore Roosevelt NP males, which were larger than Wind Cave NP males after controlling for the effects age.

Using the sex and age composition of a bison herd under a $16 \%$ annual cull (Table 1), and the mean weight for each sex-age cohort within the three parks, the mean weight of a bison at the parks was 449, 420, and $377 \mathrm{~kg}$ at Badlands, Theodore Roosevelt, and Wind Cave NPs, respectively, or $415 \mathrm{~kg}$ when averaged across the three parks (un-weighted for sample sizes). When calves are excluded the mean weight per bison would be 521, 489, and $440 \mathrm{~kg}$, respectively, or $484 \mathrm{~kg}$ when averaged across the three parks. Interestingly, the yearling-only cull practiced by Wind Cave NP increased the modeled average weight of a bison in that herd from $377 \mathrm{~kg}$ to $420 \mathrm{~kg}$. That is because the animals that escaped the yearling-only cull suffered very little mortality until they reached extreme old age, as a result the herd had comparatively more animals 8.5 years old and older.

Weights of bison when they were calves and when they were yearlings were significantly correlated with weights of the same individuals when older at both Badlands and Wind Cave NPs, except that female calf weights at Wind Cave NP were not significantly correlated with weights of females 5 years old and older (Table 4). However, there was much variability and the relationship was often weak in terms of predictive power (Figs. 2 and 3).

\section{Management Implications}

This case study provides detailed information on bison weights in the three herds, an important dataset as the herds have been the source of about 10,000 bison distributed to tribes, conservation organizations, and others entities across North America. Information regarding bison weights has important management implications. Ungulate stocking rates are often established in part on assumed animal mass. Yet surprisingly, the scientific literature is sparse in terms of providing detailed bison weight data from large datasets of known-age animals and from herds located in the Great Plains. Green and Rothstein ${ }^{10}$ and Rothstein and Griswold ${ }^{11}$ reported weights from Wind Cave NP from 1983, a sub-sample of the much larger dataset reported here. Berger and Peacock ${ }^{12}$ reported weights from 100 bison captured at Badlands NP in 1985-1986, a period prior to the dataset analyzed here. Bison weights reported from other regions might not be applicable to the Great Plains as bison weights sometimes differ greatly between regions. ${ }^{2,12,13}$ Some of the differences in the literature could be real and due to diet, genetics, or other factors; however, some of the reported differences could be due to methodology. For example, bison weights are sometimes reported simply as adult weights with no clear definition of what age classes constitute an adult. As shown here, females aged $2.5-4.5$ weigh significantly less than females aged 5.5 and older, although all are of breeding age and could therefore be classified as adults. Assuming a $16 \%$ cull of all cohorts annually, the mean weight among the parks (unadjusted for sample sizes) of females 2.5 years old and older (i.e., reproductive age) was $450 \mathrm{~kg}$, whereas the mean weight of females 5.5 years old and older (maximum weight) was $473 \mathrm{~kg}$. The detailed information reported here provides a baseline for comparisons between herds, regions, and management practices.

The results presented here show that female bison attain maximum size sometime around 5.5 years of age. Male bison appear to reach maximum size sometime around 10.5 years of age. These results are comparable to other studies. ${ }^{13-15}$ Female bison typically first breed when 2 years old, several years before they attain maximum size. Conversely, the peak age for breeding in males is around 10.5 years, ${ }^{15}$ the same age at which they attain maximum size. This is not surprising as males compete for females.

\section{Table 4. Correlation of weights of individual bison when young and when older}

\begin{tabular}{|l|l|l|l|l|l|r|}
\hline \multirow{2}{*}{ Badlands NP } & Independent & Dependent & N & Equation & Adjusted $\boldsymbol{R}^{2}$ & $\boldsymbol{P}$ \\
\hline & & & & & & \\
\hline & F Calf & F Yearling & 275 & $y=0.629 x+219$ & 0.358 & $<0.001$ \\
\hline & F Calf & F Adult (5.5+) & 130 & $y=0.351 x+449$ & 0.064 & 0.002 \\
\hline & F Yearling & F Adult (5.5+) & 101 & $y=0.208 x+432$ & 0.059 & 0.008 \\
\hline & M Calf & M Yearling & 255 & $y=0.710 x+229$ & 0.452 & $<0.001$ \\
\hline \multirow{2}{*}{ Wind Cave NP } & & & & & $<0.001$ \\
\hline & F Calf & F Yearling & 73 & $y=0.584 x+174$ & 0.194 & 0.159 \\
\hline & F Calf & F Adult (5.5+) & 53 & $y=0.265 x+370$ & 0.020 & 0.005 \\
\hline
\end{tabular}

$\mathrm{F}$ indicates female; $\mathrm{M}$ indicates male. 


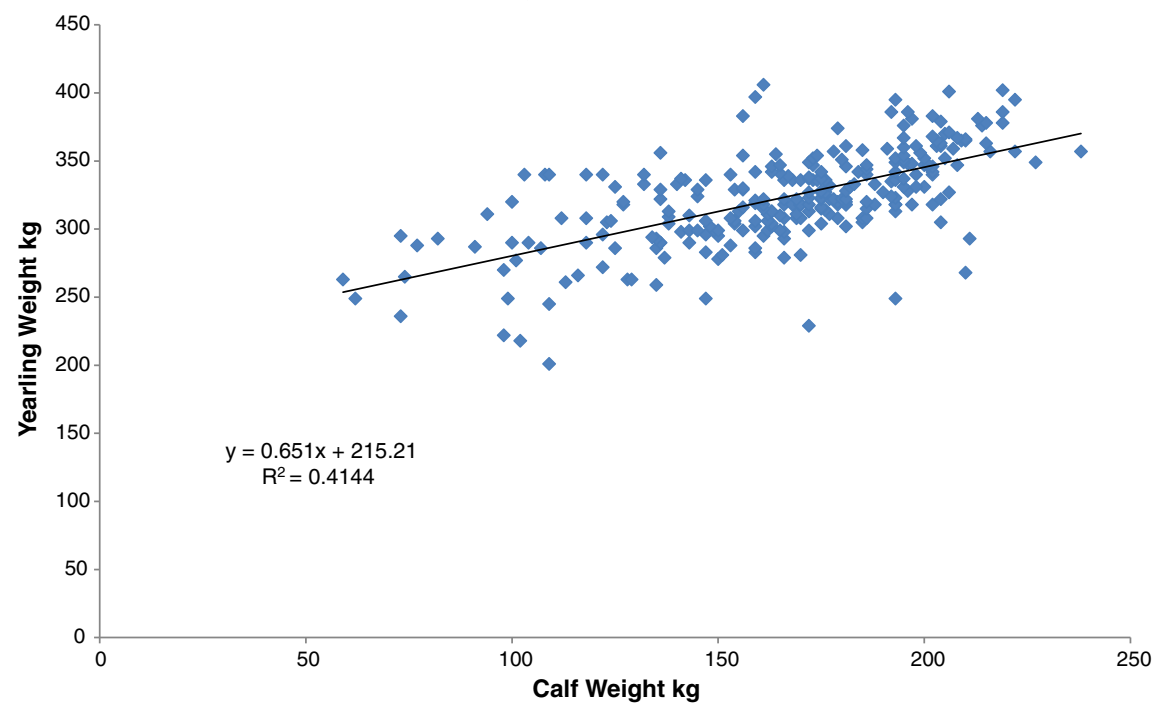

Figure 2. Correlation of same-individual female bison weights at 0.5 (calf) and 1.5 (yearling) years of age from Badlands NP.

The bison weights reported here are September-November weights, which are likely close to the heaviest weight of the year for adult bison. In late winter and early spring adult bison may be $10 \%$ lighter. ${ }^{12,16}$ Also, the calf weights reported here are likely strongly influenced by the number of days between parturition and when the animals were weighed, i.e., the date of the roundups. Although calves are typically born in early May, birthing events are often noticed well into the summer and fall at the parks. In at least one case a calf was born while the animals were confined in the roundup facilities. ${ }^{17}$

Range and wildlife managers sometimes use the concept of animal unit equivalents (AUE) to establish bison stocking rates. An AUE accounts for the difference between a "typical" bison and a $454 \mathrm{~kg}$ cattle cow and her calf. AUEs reported for bison vary from $1.8^{18}$ to $1.25^{19}$ to $1.0^{20}$ to $0.9^{21}$. The results presented here show that a "typical" bison (assuming a herd with all cohorts culled $16 \%$ annually) weighs about $415 \mathrm{~kg}$, or 0.91 of a cattle cow-calf pair, suggesting an AUE around 0.9. However, intake rates of bison appear to be only about 0.9 of cattle intake rates, at least in northern climates, ${ }^{16}$ so an even lower AUE would not be unreasonable. For more precise management I recommend that bison managers establish forage-based stocking rates using known or assumed age and sex-specific bison weights, the composition of the herd,

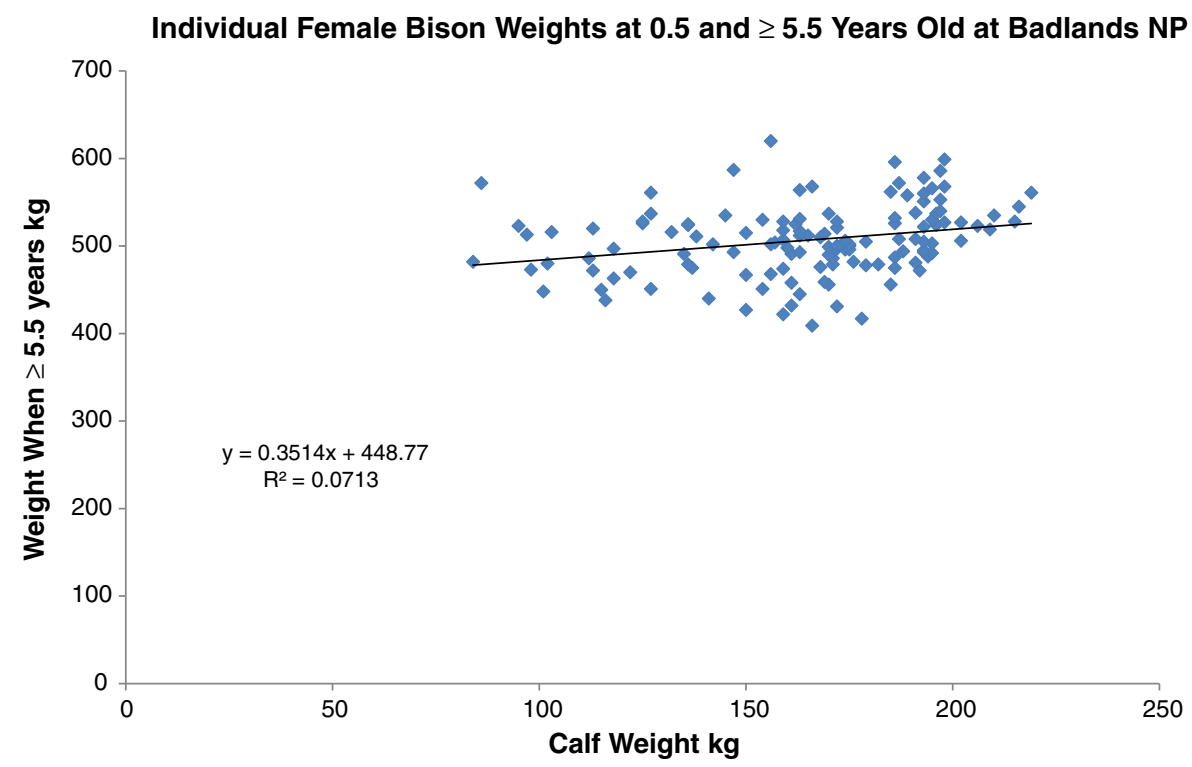

Figure 3. Correlation of same-individual female bison weights at 0.5 (calf) and $5.5+$ (adult) years of age from Badlands NP. 
assumed forage consumption rates ${ }^{16}$, and the desired forage allocation to bison.

The collection and reporting of detailed information on bison weights has implications beyond establishing stocking rates. For example, within the federal government there have been ongoing discussions about mixing bison between herds as a way to avoid inbreeding depression and to better conserve genetic diversity. ${ }^{22}$ Yet, with such a large disparity in weight among herds it is possible that males from one herd would be dominant over males from another herd should they be mixed. The result could be genetic swamping, outbreeding depression, or population stratification. Some of these effects occurred when smaller male bison were supplemented to Badlands NP in 1984. ${ }^{15}$ Another reason to collect weight information in the National Park Service herds is to track changes over time. Ecological theory suggests that the bison might become smaller over time due to climate change ${ }^{13}$ and the absence of large predators.

Further research is warranted regarding the differing weights between the herds. It does not appear to be due to the forage quantity as all three herds are stocked well below the forage-based carrying capacity. It could be due to forage quality. It could also be due to the lineages of the herds. The three bison herds I analyzed have been the source of approximately 10,000 bison distributed to other sites to start new herds or to augment existing ones. ${ }^{17,18}$ Recipients of NP bison should monitor the weights of the bison in their herds as that could provide clues to whether the disparity in the three herds is forage-based, genetic, or due to some other factors. Similarly, the three park units evaluated here should continue to collect accurate data on their valuable bison herds.

\section{Acknowledgments}

I thank G. Schroeder, B. McCann, E. Childers, D. Roddy, B. Muenchau, and D. Uresk for reviewing the paper. I thank all the people involved in the capturing of bison and data collection.

\section{References}

1. Licht, D.S. 2014. Bison (Bison bison) restoration and management options on the South Unit and adjacent range units of Badlands National Park in South Dakota: A technical evaluation. Fort Collins, CO, USA: National Park Service. 83 pp.

2. Reynolds, H.W., C.C. Gates, and R.D. Glaholt. 2003. Bison. In: Feldhamer GA, Thompson BC, \& Chapman JA, editors. Wild mammals of North America: biology, management, and conservation. Baltimore, MD, USA: The John Hopkins Press. 1216 pp.

3. National Park Service, 2006. Management policies: The guide to managing the National Park System. Washington D.C., USA: National Park Service. 274 pp.

4. Gates, C.C., C.H. Freese, P.J.P. Gogal, and M. Kotzman. 2010. American bison: Status survey and conservation guidelines 2010. Gland, Switzerland: International Union for the Conservation of Nature. 134 pp.
5. Natural Resources Conservation Service, 2014. Web Soil Survey. Available at: http://websoilsurvey.sc.egov. usda.gov/App/HomePage.htm2014 Accessed 14 October 2014.

6. Pyne, M.I., K.M. Byrne, K.A. Holfelder, L. Mcmanus, M. Buhnerkempe, N. Burch, E. Childers, S. Hamilton, G. Schroeder, AND P.F.J. Doherty. 2010. Survival and breeding transitions for a reintroduced bison population: A multistate approach. J Wildl Manag 74:1463-1471.

7. Fuller, W.A. 1959. The horns and teeth as indicators of age in bison. J Wildl Manag 23:342-344.

8. Motulsky, H.J., ANd R.E. Brown. 2006. Detecting outliers when fitting data with nonlinear regression - a new method based on robust nonlinear regression and the false discovery rate. $B M C$ Bioinformatics 7:123.

9. Millspaugh, J.J., R.A. Gitzen, D.S. Licht, S. Amelon, T.W. Bonnot, D.T. Farrand-Jones, D.S. Jachowski, B.J. Keller, C.P. Mcgowan, M.S. Pruett, C.D. Rittenhouse, and K.M.S. WELLS. 2008. Effects of culling on bison demographics in Midwestern National Parks. Nat Areas J 28:240-251.

10. Green, W.C.H., And A. Rothstein. 1991. Trade-offs between growth and reproduction in female bison. Oecologia 86:521-527.

11. Rothstein, A., And J.G. Griswold. 1991. Age and sex preferences for social partners by juvenile bison bulls, Bison bison. Anim Behav 41:227-237.

12. Berger, J., And M. Peacock. 1988. Variability in size-weight relationships of Bison bison. J Mammal 69:618-624.

13. Craine, J. 2013. Long-term climate sensitivity of a grazer performance: A cross-site study. PLoS One 8e67065.

14. Olson, W.E. 2002. Plains and wood bison weight and population dynamics in Elk Island National Park for 2001-2002. Fort Sasketchewan, AB, Canada: Elk Island National Park.

15. Berger, J., and C. Cunningham. 1994. Bison: Mating and conservation in small populations. New York, NY, USA: Columbia University Press. 330 pp.

16. Feist, M. 2000. Basic nutrition of bison. Saskatchewan, Canada: Agriculture Knowledge Center, Saskatchewan Agriculture. 20 p.

17. Licht, D. S. accepted for publication. The need for reliable funding for bison management. The George Wright Forum.

18. HolecheK, J.L. 1988. An approach for setting the stocking rate. Rangelands 10:10-14.

19. Bragg, T.K., B. Hamilton, and A. Steuter. 2002. Guidelines for bison management: Arlington. VA, USA: The Nature Conservancy.

20. Ogle, D., and B. Brazee. 2009. Estimating initial stocking rates. TN Range No. 3. Boise, ID, USA: USDA - Natural Resources Conservation Service. $11 \mathrm{pp}$.

21. Miller, K.L. 2002. Planning for bison grazing on native rangeland. Washington, D.C., USA: USDA - Natural Resources Conservation Service. 6 pp.

22. Dratch, P., And P. Gogan. 2008. Bison conservation initiative: Bison conservation genetics workshop: report and recommendations. Fort Collins, CO, USA: Department of the Interior.

Author is Regional Wildlife Biologist, Midwest Region, National Park Service, 231 East Saint Joseph Street, Rapid City, SD 57701, USA. Research was funded by the National ParkService (Licht; dan_licht@nps.gov). 